\section{A Biopolitics of Immaterial Labor}

\author{
Daniel Just \\ Bilkent University
}

Political Studies 20I6, Vol. 64(2) 40I-4I6

(C) The Author(s) 2015

Reprints and permissions: sagepub.co.uk/journalsPermissions.nav DOI: I0.1 I I I/I467-9248.12185 psx.sagepub.com

\begin{abstract}
This article examines Michael Hardt and Antonio Negri's and Paolo Virno's use of Michel Foucault's notions of 'biopower' and 'biopolitics' with respect to today's hegemony of immaterial labor, i.e. work without an end product. In spite of relatively infrequent references to work, Foucault formulates these notions in markedly economic terms: biopower is inextricable from work because, unlike punitive power that represses and disciplines life, it cultivates life by fostering an efficient, productive and active population. Drawing attention to a shift in emphasis in Hardt and Negri's and Virno's accounts of work and biopower - from a diagnostic analysis of labor practices to immaterial labor's latent political possibilities - it is argued in the article that what gets lost in this shift is Foucault's insistence on questioning the role of work in modern society. Work is not an inherently valuable activity, but, as current contradictions that have emerged with immaterial labor demonstrate, a product of mechanisms which endow it with its present status as the central organizing principle of both social and personal life.
\end{abstract}

Keywords: biopower; Foucault; work; Hardt and Negri; Virno

Michel Foucault's notions of 'biopower' and 'biopolitics' have had enormous impact on our understanding of how modern power operates. This article examines Foucault's later texts in which these notions are developed, paying particular attention to how he links them to changes with respect to work and economy. The first part of the article discusses how changes in the perception of the human body, health and disease that took place in the late eighteenth century affected new policies regarding hygiene, demography, sexuality and circulation of human resources. Together with other changes that pertained to work more directly (e.g. loans, saving funds, reforms in education), these policies were part of larger biopolitical changes that transformed modern society along the lines of economic efficiency and productivity. The second part turns to recent changes in global economy and patterns of work. Centered on Michael Hardt and Antonio Negri's and Paolo Virno's conceptualization of today's hegemony of immaterial labor (that is, work that results in no material or durable commodity), this part discusses the increasing value of cooperation and communication in contemporary labor practices, the progressing erasure of work's temporal and spatial boundaries, and the alleged greater autonomy and creativity of workers. The third part returns to Foucault to consider Hardt and Negri's and Virno's application of his notions of biopower and biopolitics on immaterial labor. Raising the issue of immaterial labor's contradictions that have been either omitted or downplayed by Hardt and Negri and Virno, this part questions the latter's optimism and shift of focus to immaterial labor's latent political potential because this shift disregards the main thrust behind Foucault's notions: work is not intrinsically valuable - its central role in modern society is a result of power mechanisms that have made it into something socially vital, politically compelling, culturally normative and personally desirable. 


\section{Work and Modern Biopower}

In the conclusion of his lecture course Society Must Be Defended, Foucault outlines his theory of two types of power. Until the mid-eighteenth century, power was practiced primarily in the form of the 'anatomo-politics of the human body' (Foucault, 2003a, p. 243). Focusing on the body, this type of power disciplined people by breaking their mass into individual bodies that could be controlled, trained and punished. In the latter half of the eighteenth century, another form of power started emerging that soon became dominant, although it sometimes continued to rely on disciplinary methods. This new technology of power - 'this biopolitics, this biopower' (Foucault, 2003a, p. 243) - focused not on the body as an object, but on humans as living beings. This shift in power from man-as-body to man-as-species altered the way power would henceforth operate.

With the emergence of biopower, the object of power shifts away from people as a sum of individual bodies to people as a global mass. Unlike political anatomy which was individualizing and disciplining, the new biopolitics of the human species is massifying: biopower regulates the population as a whole and manages it as a group exposed to various processes that affect life and its well-being (e.g. birth, death, illness). Both forms of power have direct effects on the body, but while the former individualizes it, the latter returns it to larger biological processes. Concerned with health, longevity and the rate of reproduction, biopower fosters life rather than represses it. For example, biopower changes the perception of disease from a terminal predicament that threatens survival - the deathdealing epidemics afflicting medieval societies that dealt primarily with the maladies' aftermath - to a social nuisance. ${ }^{1}$ The interest turns to the most frequent illnesses that affect the welfare of the population. In other words, disease becomes an issue of economy. What matters are the detrimental economic consequences of diseases as they weaken life, slow the rate of production and increase the cost of health care. Mechanisms introduced to deal with this new situation differ from the previous repressive procedures. Mechanisms such as statistical data, estimates and forecasts are not meant to affect any specific phenomenon or individual. Their purpose is to intervene at a level where more general phenomena are determined: 'The mortality rate has to be modified or lowered; life expectancy has to be increased; the birth rate has to be stimulated' (Foucault, 2003a, p. 246). By establishing an equilibrium that equalizes variations within the general population, the goal of new biopolitical mechanisms is to optimize the state of life and cultivate it.

Even sexual liberation and the loosening of constrains on speech about sex, Foucault argues in The History of Sexuality: The Will to Knowledge, are an outcome of these changing technologies of power. The new paradigm of sexuality that urges people to engage in sexual matters is no longer the old-fashioned repression, but a positive type of power that takes care of the population by assuring its health. Using the same concepts of the 'anatomo-politics of the human body' and 'bio-politics of the population' as in Society Must Be Defended, Foucault defines the former as a disciplining power that centers on the body as an object and tool - extorting its energies, rectifying its capabilities and increasing its docility - and the latter as a power that focuses on the body imbued with the mechanics of life and serving as the basis of the biological processes: propagation, births and mortality, the level of health, life expectancy and longevity' (Foucault, 1978, p. 139). Although 
biopower does not entirely replace disciplining power, it nevertheless gradually attains hegemony over it by instituting effective means of regulation, such as demography, evaluation of resources, and assessment of wealth and its circulation, that bolster the population's strength and productivity (Foucault, 1978, p. 140).

While neither Society Must Be Defended nor The Will to Knowledge takes economy as its primary subject, they both discuss biopower in markedly economic terms. Originating in the rapid increase in production and resources in the eighteenth century, which brought relief from the profound threats of death by famine and epidemics to which humanity was hitherto exposed, biopower complemented this material development by providing an awareness of the sudden realization of what it meant to be 'a living species in a living world': to have 'probabilities of life, an individual and collective welfare, forces that could be modified, and a space in which they could be distributed in an optimal manner' (Foucault, 1978, p. 142). Areas as diverse as health, demography and sexuality were part of this recalibration of power along the lines of economic efficiency and productivity that became the driving force of modern society. From that moment on, resources would be an object of explicit calculations and mechanisms of human life an issue of production, efficiency and productivity. Power would no longer deal with legal subjects over whom coercion is exercised with the ultimate authority of death. It would deal with living beings and their usefulness to the economic welfare of the population as a whole.

Indeed, in certain areas of modern society the mechanism by which the biopolitical shaping of human life has mobilized work continued to rely on disciplinary methods. But even in these areas the goal was not punishment, but correction. Symptomatically, work became part of the 'technique of improvement' of delinquents who were no longer bodies to be punished, but potentially productive members of society to be 'cured' and 'reclaimed' (Foucault, 1995, p. 10). This shift in the disciplining procedure shows that the modern consecration of life through work was linked to broader changes in the perception of punishment and death. According to Foucault, it is no accident that the end of the eighteenth century was the time of the dawn of biopower and the modern paradigm of work, as well as the moment of radical changes in punitive practices and the period of acceleration of the process of exclusion of death from private and public life (Foucault, 2003a, p. 247). Before biopower, death was a glorious phenomenon marked by personal rituals (last words, final wishes, periods of mourning) and public spectacles (tortures, executions). With the emergence of biopower, death and punishment ceased to be grand rituals and became instead a thing to hide. What set in motion the transformation of corporeal punishment, renunciation of death and the concomitant glorification of work were shifting technologies of power. While at times falling back on disciplinary procedures, the new technology of power pertained not to individual bodies, coercion and the dispensation of death, but to population, promotion of life, and endorsement of activity and productivity.

Many new mechanisms were introduced in the late eighteenth and early nineteenth centuries in the name of population welfare. In modern times, health insurance and hygiene rules were established in order to secure the optimal age of the population; pension and saving funds were introduced to foster a more flexible workforce; student loans were made available to enable people to acquire needed work qualifications; and tax 
deductions, maternity leave and day care were instituted to encourage reproduction and allow for workers' greater availability (Foucault, 2008, pp. 185-213). According to Foucault, all these mechanisms are forms of investment of power in human capital, and as such should be analyzed as concrete strategies through which power is exercised. Special attention must be paid to how entrepreneurs utilize these strategies and how workers respond to them.

Foucault reproaches classical political economists, especially Ricardo, Keynes and Marx, for analyzing labor as something abstract, passive and reduced to the factor of time (Foucault, 2008, p. 220). For Ricardo, labor is an issue of quantity, a factor of time inserted between capital and production, with the increase in labor signifying merely that more hours are offered to capital (either workers work longer hours or more of them are hired). For Keynes, labor is a factor of production, and what activates it is a sufficiently high rate of investment. For Marx, labor is the effect of produced value, an abstract capacity measured by time that is placed on a market which determines its monetary value. In spite of their different conclusions, Ricardo, Keynes and Marx are similar in their approach in that they separate labor from human reality and qualitative variables.

Foucault sides with neoliberal economists, arguing that when labor does not appear in concrete terms, it is not the fault of real capitalism, but of economists who fail to grasp the concrete modulations of labor and their economic effects (Foucault, 2008, p. 221). He insists that the abstract image of labor is a result of economists focusing solely on capital and its processes (machines, investments and products). Labor is not abstract; it is the point of view towards labor that turns it into an abstraction. The focus should be less on structures and large processes, and more on concrete practices studied from the perspective of the strategic rationality of those involved in the labor process. As the calculations of workers and entrepreneurs who allot their scarce resources (money and time) to one end rather than another, work must be seen as an 'economic conduct practiced, implemented, rationalized, and calculated by the person who works' (Foucault, 2008, p. 223).

Foucault's insistence on analyzing labor in concrete forms, as an outcome of biopolitical forces that regulate work by activating workers and inciting their engagement in the activity of working, does not call merely for a shift of focus from the worker as an object to the worker as a subject. Since biopower is both physical operation and the discourse that upholds it, it not only generates a new form of labor. Nor is the issue solely the fact that biopower makes workers an active component of this new labor. All of these concerns are important, but they rest on a more modest observation: the fact that biopower establishes work as something natural. Biopower makes work an unquestioned value, which in turn promotes a certain way of life dominated by work. In addition to revealing how the practices of work operate, analyses of work must draw attention to the fact that in the modern era both material life and knowledge about it emerge as always already staked out by a given set of values, notions and power relations. Foucault is clear on this: man is not a worker; he is made into one. Work, he proclaims, 'is absolutely not man's concrete essence or man's existence in its concrete form'; for people to be tied to work an operation is necessary by which they are 'effectively - not analytically but synthetically - bound to the production apparatus for which they labor' (Foucault, 2001a, p. 86). 
In the age of biopower, people are attached to work by an operation that is both profoundly political and operates at the level of people's very existence: control over their time. Unlike feudal society, which controlled individuals on the basis of space, modern society cares about individuals' spatial ties only to the extent of claiming their time. Beginning in the late eighteenth century when poverty became an unacceptable form of idleness that had to be eliminated, biopower adapted people to the needs of production and made them into a labor force by molding their time into labor time (Foucault, 2001b, p. 93). All of one's available time was mobilized and labor imposed onto the time of one's entire existence. At this point, work penetrated human life to such an extent that it was no longer just the time of the work day, but the whole lifespan that could be used in the best way by the production apparatus (Foucault, 2001a, p. 81). Institutions whose professed function it was to offer protection and security served as a means of ensuring that the entire population and the whole time of human existence were inscribed into the labor market. For example, amid wage raises in France and England in the 1840s and 1850s, this surplus of money was deposited into workers' savings funds not in order to improve their comfort, but for their future use in case they lost their jobs. These mechanisms were part of larger biopolitical forces whose goal it was to guarantee the population's productivity and the market's flexibility, as employers needed to hire and dispose of workers freely, without nonetheless letting them die of hunger before they were needed again (Foucault, 2001a, p. 81). Foucault concludes that these forces that adjusted people to the demands of accumulated capital in turn accelerated the accumulation of capital (Foucault, 1995, p. 221).

\section{Recent Changes in Patterns of Work and Power}

Foucault's notions of biopower and biopolitics have received ample attention in recent years. Most notably, with respect to the issue of work, Michael Hardt and Antonio Negri, and Paolo Virno have used them to explain current changes in the global economy. ${ }^{2}$ Hardt and Negri's Empire trilogy - Empire, Multitude and Commonwealth - offers the most comprehensive contribution to date concerning the role of work in today's biopolitical shaping of life. Their main argument suggests that with the hegemonic role of immaterial labor, the production of social relations has become an immediate effect of the act of working, with workers now having direct hold over social space because immaterial labor involves communication and social interaction directly and instantaneously. It is not that production becomes communication, which consequently turns into social interaction; rather, immaterial labor is coextensive with communication, and communication is coextensive with social interaction - facts that make work a potential place for a democracy that is practiced directly, with no delays and no intermediaries.

Hardt and Negri's concept of immaterial labor is a result of major changes in labor patterns over the past few decades. Scholars agree that the relevance of work across different fields of contemporary society as the primary means by which individuals are integrated into their economic, social and political environment has risen sharply (Beck, 2000; Muirhead, 2004; Weeks, 2011). Globalization and information technology have fundamentally altered the rational organization of work that followed the Industrial Revolution. With more and more work becoming immaterial it is no longer work that 
creates wealth, but wealth that creates work (Gorz, 1999, p. 56). This 'new spirit of capitalism' (Boltanski and Chiapello, 2007) brought a new organization of work: decentralized management, greater flexibility of production, the outsourcing of jobs, risk-shifting from employers to employees, an emphasis on team work and project work, and the restructuring of employment in the direction of temporary contracts, sub-contracts and self-employed workers. Whereas Fordism led to the infamous de-skilling of workers, post-Fordism requires a skilled workforce because it is driven by the demand for quality products, variety and wide-ranging services. To facilitate this reorganization of work, various mechanisms have been introduced to increase workers' stakes in the work process. Control over work is now exercised by performance measures rather than working hours, teamwork is combined with personal rewards, and increased interaction in collective projects results in peer pressure and other self-motivating devices (Casey, 1995, pp. 121-2).

These changes have generated important effects for individual workers as well as society at large. On the level of individuals, the shift to non-permanent forms of employment (freelancing, part-time jobs and fixed-term contracts) has forced workers to be more involved in the changing landscape of work (Arthur and Rousseau, 2001). People now need to know which skills to develop, and since the working process helps them in doing so, working more and in a more engaged fashion enhances not only the product of one's immediate work, but also one's skills, and thus one's chances of succeeding in the volatile job market (Hall and Soskice, 2001, p. 30). On the level of the workforce, the 'unbounding' of traditional forms of work has substantially reduced the likelihood of dissent (Gottschall and Wolf, 2007, p. 12). Although workers now interact more, mechanisms that have increased their stakes in the game have lowered their capacity to mobilize politically, the result being a steady decline in unionized action, with strikes becoming fewer, shorter and sometimes even outlawed. On the level of the social sector of labor, there has been a palpable decrease in benefits (social security, pensions and health care) and an upsurge of unemployment and underemployment (though a rising employment of women) (Kalleberg, 2009). And, last, in terms of larger social effects, changes in labor patterns have brought, on the one hand, a greater freedom of movement and working hours, and, on the other, a mounting tendency to work more, both enforced by employers and self-induced (Fleming, 2009; Ross, 2004).

Hardt and Negri's theory of immaterial labor is formulated against this background of fast transformation of work in the direction of greater flexibility, efficiency and productivity. Unlike those who have addressed this transformation as 'the end of work' (Rifkin, 1996), Hardt and Negri regard the fact that work is no longer defined and expressed by labor time as part of a larger historical process which amplifies, rather than decreases, the political relevance of the activity of working. The current blurring of work's temporal and spatial boundaries - the fact that work is no longer tied to given working hours and designated workplaces, but has instead spread throughout society and into what used to be leisure time and one's life outside of one's job - is an outcome of wide changes in material and social life. According to Hardt and Negri, labor has become truly biopolitical because, more than any previous form of work, the current model is defined not by the extent of control (norms, rules and restrictions), but by the ability to produce concrete forms of life and distinct modes of social, cultural and political existence. 
For Hardt and Negri, work is a 'restless activity'; 'living labor', a source of 'deterritorializing desire' (Hardt and Negri, 2000, p. 52). They propose that work be seen not from the point of view of capitalist processes of valorization - as a figure of equilibrium - but as an instance of self-valorization - 'as an antagonistic figure, as the subject of a dynamic rupture of the system' (Hardt and Negri, 1994, pp. 8-9). Challenging the traditional Marxist notion of labor power as a variable of capital (labor as a force that is activated and coordinated by capital), they insist that labor is an activity that both activates and valorizes itself. The recent move with the largest share of work shifting from industrial factory work to immaterial and affective labor is the latest stage in the development of this living labor. At this stage, labor finally capitalizes on its self-valorizing potential. In immaterial labor, communication and cooperation are no longer incited by the capitalist; they are immanent to the activity of working and arise from the productive energies of labor itself (Hardt and Negri, 2004, p. 113). In today's economic and social reality - which is defined more and more by collectively produced services and less and less by material objects, their production, circulation and consumption - immaterial labor is increasingly autonomous from capitalist control. In an environment in which external forces are obstacles rather than catalysts of work, workers spontaneously create horizontal networks of communication and cooperation that facilitate production. Since producing now means 'constructing cooperation and communicative commonalities' (Hardt and Negri, 2000, p. 302), immaterial labor is instantly a site of social interaction.

By relying on cognitive habits of speech and thinking that are generic capabilities of humans as a species, immaterial labor stimulates what all people have in common. Paolo Virno argues that with immaterial labor 'the monological feature of labor dies away' (Virno, 2004, p. 63), and linguistic integration and cooperation become a driving force, not an accessory. The main effect of this change on the organization of labor is its de-compartmentalization. The sharing of speech and thinking undermine the division of labor that characterized work as material production, because although work is still subdivided, the distribution of duties is now reversible and not determined by objective technical criteria. Quoting from Luciano Bianciardi's novel La vita agra - 'How can one evaluate a priest, a journalist, a public relations person? How can one calculate the amount of faith, of purchasing desire, of likeability that these people have managed to muster up?' (Virno, 2004, p. 57) - Virno describes immaterial labor as a 'performance' of communication, calling it 'virtuosity without a script', 'a virtuosic performance (without end product)' (Virno, 2004, pp. 66 and 55). The consequence of this turn to performance is twofold. First, immaterial labor enables more autonomy and creativity; and, second, it increases the proportion of non-labor in the production process. Regarding the first, managers no longer coordinate workers because the work process is itself a form of coordination. Workers' know-how is not an object of surveillance anymore, with reorganization of labor no longer being an adaptation to workers' creative ways of executing labor with less effort. Instead, the discovery of expedients of labor has been made into workers' own initiative. Workers are now asked to invent new cooperative procedures that will make their work more efficient. Regarding the second consequence, non-labor has become a more prominent component of production than labor itself. Arguing that in the 
post-Fordist era 'production time is interrupted only at intervals by labor time' (Virno, 2004, p. 104), Virno claims that the worker now coordinates (i.e. labor time) the automatic system of machines (i.e. production time not directly invested with labor) only sporadically, merely extending the non-labor time during which social cooperation takes place.

The theory of immaterial labor developed by Hardt and Negri and Virno draws a direct link between this form of labor and politics. Challenging Hannah Arendt's argument that economic activities are irrelevant for political life because they imply repetitive tasks and the mechanical following of instructions, while politics requires autonomy, creativity and communication, Hardt and Negri and Virno oppose Arendt's insistence on the growing depoliticization of modern life due to changes in the nature of the working activity. According to Arendt - who distinguishes between work and labor, linking work with the use-value of objects and artisanal skill, and labor with tedious toil, consumption and the mere preservation of life - modern society is increasingly less political because it erases the difference between labor, work and politics as three fundamentally inseparable spheres of human activity. For Arendt, work and labor are 'unpolitical' (Arendt, 1958, p. 208) as politics designates activities whereby 'each individual in his unique distinctness appears and confirms himself in speech and action' (Arendt, 1958, p. 207). The modern world is depoliticized because it has turned the least political aspect of life (manual labor) into life's central modus operandi. In the modern world of mechanization, use-objects as creations of work have become consumer goods that are mass manufactured and mass consumed. The result of this shift is that manufacturing activity has been elevated to the point 'of leveling all human activities to the common denominator of securing the necessities of life and providing for their abundance' (Arendt, 1958, p. 126).

Hardt and Negri and Virno insist that the distinction between labor, work and political action introduced by Arendt is no longer applicable. The strict division between the private and the public, which Arendt attributes to ancient Athens under Pericles where she finds a short-lived purity of unadulterated political action outside the realm of work and labor, is no longer valid. With the political, the social and the economic now inseparable, activities that previously related only to the political - exchanges of ideas by means of language and the cooperation of distinct individualities who in so doing create a common social space - now apply to the economic as well. In the contemporary world of instability of the division between nature and artifice, public and private, and work and labor, social practices pertain simultaneously to all three planes: labor, work and political action. Labor now encompasses practices that address, at the same time, "natural" needs, "artificial" desires, and social relationships' (Hardt and Negri, 1994, p. 315, n. 2). Hardt and Negri choose the term 'biopolitical' to name these new economic acts that are 'immediately political (2009, p. 174)'.

Virno agrees with Hardt and Negri that as soon as language and thought become the primary sources of the production of wealth, labor acquires political qualities and becomes biopolitical. 'Things have gone in the opposite direction from what Arendt seems to believe', Virno avows: 'It is not that politics has conformed to labor; it is rather that labor has acquired the traditional features of political action (2004, p. 51).' Political interaction with others, defined as openness to contingency and otherness, as well as the origin of new social processes, is now located in the world of labor. Operating outside temporal and 
spatial regimentation, immaterial labor is a flexible, productive and self-valorizing act of self-making that is an instant political force. Hardt and Negri call the vehicle of this political force 'multitude'. They define it as an 'open and expansive network in which all differences can be expressed freely and equally' (Hardt and Negri, 2004, p. xiv). Although the economic aspect of the multitude is central to it - 'the common we share is not so much discovered as it is produced' (Hardt and Negri, 2004, p. xv) - the multitude is neither a class (a homogeneous class, such as the working class), nor an identity (a single identity, like 'the people'), nor a unity (a uniformity, such as the masses). The multitude is a multiplicity of differences (races, cultures, genders, professions and ways of living) that do not disappear when individuals who compose the multitude act, produce, communicate and cooperate. Even though they admit that the multitude produces everywhere all day long, because 'there are no time clocks to punch on the terrain of biopolitical production' (Hardt and Negri, 2000, p. 403), they believe that this erasure of work's boundaries distinct space (factory, office) and time (working hours) - turns the predicament of no boundaries into something that, like the multitude, is essentially affirmative. For them, immaterial labor is a harbinger of a positive course of democratic changes and the promise of a radical social transformation in the future.

\section{A Biopolitics of Immaterial Labor}

The biopolitical mechanisms of work described by Foucault in their eighteenth- and nineteenth-century manifestations, then largely dependent on the state, by now have become increasingly driven by transnational forces that are changing the nature of work worldwide. It is in order to describe this new world of labor that Hardt and Negri and Virno redeployed the concept of biopower. The question is to what extent they have succeeded, and whether they have managed to deal with concrete labor practices, as Foucault insisted any application of the concept of biopower should. Hardt and Negri, and to a lesser extent Virno, are enthusiastic about the turn to immaterial labor. ${ }^{3}$ Unlike Foucault, who remained diagnostic and neutral, if not critical, Hardt and Negri adopt a theoretical perspective from which a number of vastly diverse facts about contemporary work appear as either positive or at least with positive potential.

The most obvious critique of the celebration of immaterial labor is that the majority of workers are still material producers. On some level, this is not a fair reproach. Hardt and Negri present immaterial labor as a figure of hegemony - i.e. not a quantitative fact, but a qualitative one: immaterial labor is an exemplary form of labor that plays a crucial structural role, serving as an impetus for changing other types of labor. What is more problematic about Hardt and Negri's position is that it does not account for the process by which material labor is made invisible and its traces replaced by signs of immaterial labor. Metropolitan areas, such as Dubai, Singapore and Los Angeles, are presented as hubs of immaterial labor, but that has been made possible only by making material laborers (often foreigners) invisible. But even more problematic is the choice of professions on which Hardt and Negri and Virno model their notion of immaterial labor. Immaterial workers, such as journalists, teachers, doctors, scientists, lawyers and academics are rarely the freed laborers Hardt and Negri and Virno imagine them to be. Many of these workers' practices are far from democratic, with their conduct embedded in given pathways through 
networks and constrained by large technological systems (Luke, 2006, p. 368). Furthermore, what is supposedly performance without measurable products - the immeasurable work evoked in Virno's reference to La vita agra - is always measured. Mechanisms resembling old-fashioned quotas have been instituted to quantify immaterial labor. For instance, in academia work is evaluated by the number of published articles, the impact factors of journals in which they appear, the number of citations, student evaluations of classes, peer reports on teaching performances, the number of supervised theses, and success in placing graduates. The situation is similar for material laborers whose work has been supposedly immaterialized. Workers hardly ever engage in non-labor between their sporadic intrusions of labor into the production process, as Virno argues. Workers work all the time when on the job, because even when only maintaining machines, the organization of labor has assured the best possible utilization of their time. Workers' labor appears as interruption only from the perspective of production time. From the perspective of the working activity, labor time is a continuous act, not an interruption: workers continuously maintain as many machines as has been established as feasible so as to reach a maximum level of efficiency and thus the lowest possible cost.

The problem with Hardt and Negri's and Virno's theory of immaterial labor is that their interpretation of the biopolitical mechanisms that affect labor conflates reality and potentiality. The issue at stake is not to decide whether the aspect of communication and cooperation in immaterial labor is political - because, as Hardt and Negri claim, the boundary between work and the political has been erased in immaterial labor - or whether, on the contrary, this aspect is a byproduct of the larger historical process of labor taking over everything, including the political, as Arendt suggests. Foucault's concept of biopower renders any such definite conclusions precipitous. His insistence on analyzing labor practices in their concreteness urges against analyses that are too entrenched in pre-existing agendas and driven by prognostic motivations. Emphasizing more the positivity of labor's autonomy than its possible autonomy (Holloway, 2010), Hardt and Negri's and Virno's take on immaterial labor offers a scenario in which all aspects of immaterial labor appear as affirmative and democratic. Admittedly, they occasionally address phenomena that do not immediately fit into their theoretical model, such as precarity and homogenization. Hardt and Negri, for example, acknowledge that due to job insecurity workers are often forced to hold multiple jobs. Precarity, they explain, 'is a mechanism of control that determines the temporality of workers, destroying the division between work time and non-work time, requiring workers not to work all the time but to be constantly available for work' (Hardt and Negri, 2009, p. 146). They also admit that current changes in computer and information technologies have weakened the structural resistance of labor power, leading simultaneously to 'furious and unrestrained competition among workers' (Hardt and Negri, 2000, p. 337) and a homogenization of the labor process that increasingly further remove[s] [workers] from the object of [their] labor' (Hardt and Negri, 2000, p. 292). However, instead of analyzing how these mechanisms operate, which effects they generate, and how they affect both workers and employers, they turn to their positive aspects and political potential for radical social transformation.

For Hardt and Negri, capital and workers are two opposing forces, the former being negative and reactive, and the latter positive and active. Downplaying capital's creative and 
deterritorializing side - oddly, because it is often emphasized by Gilles Deleuze, their frequent point of reference - they argue that 'the history of capitalist forms is always necessarily a reactive history', and that it is the proletariat which invents 'the social and productive forms that capital will be forced to adopt in the future' (Hardt and Negri, 2000, p. 268). Indeed, the proletariat plays a vital role in social and economic changes. For instance, the move from Fordism to post-Fordism has been in many places facilitated by workers' resistance to the Fordist rationalization of work and by their demand for more complex jobs so they cannot be as easily replaced as when their tasks require only elementary skills. But changes of this magnitude are never simply brought about by the proletariat. While the proletariat is not a passive $\operatorname{cog}$ in the machine of worldwide capital, it is also not a purely creative agent opposed to reactionary capital. Social and economic changes result from the interplay between capital and workers, which is never unidirectional and driven by the proletariat alone. In the case of immaterial labor, cooperation and communication are as much products of this interplay as precarity and homogenization, with none of these effects and attributes of labor being scripted by the proletariat. The proletariat does not invent the new forms of production that capital adopts in the future. It is capital that invents them, albeit through overcoming the proletariat's resistance and obstructions. Even in cases where resistance is limited, or without tangible consequences, capital still, though more slowly and less inventively, follows the path of adjusting work and production in search of more profit.

Hardt and Negri's portrayal of immaterial labor undervalues two facts. First, that part of the impulse that drives the process of the transformation of work are people's needs and desires, which multiply in direct proportion to the amount of work that is needed to fulfill them (in other words, needs and desires are introduced by capital together with the necessary means of satisfying them); and, second, that in order to yield more profit, capital, by introducing both new needs and new ways to meet them (immaterial labor, multiple jobs, flexible hours, freelancing), establishes these new forms of work as the new hegemony. In this process, economic crises are inevitable because of the fundamental opposition in capitalism between use-value and exchange-value. As the logic of capital and profit speculation makes the realm of exchange-values increasingly detached from the realm of real needs, use-values and people's productive capabilities, crises become ever more severe (Marx, 1991, pp. 355-68). As moments of market corrections, economic crises are blow-backs of reality that expose the fantasmatic nature of capitalist speculation and the destructive side of capital's evolutionary process of 'creative destruction' (Schumpeter, 2003 , p. 83). It is only emblematic that the rapid acceleration in the availability of temporary contracts at the expense of full-time jobs occurred in the aftermath of the recent financial crisis and the ensuing recession. After this moment, more flexible forms of work have become the necessary solution to the crisis. In the cyclical process of capital instituting new needs, introducing new modes of labor to satisfy them, undergoing a crisis, and surviving it by establishing these new modes of labor as the new norm, workers have a less active role and capital, conversely, a less reactive role than Hardt and Negri believe.

Hardt and Negri's postulation of workers as the multitude - an immanent force that as a historical agent is repressed by other forces, such as sovereignty and capital, that prevent it from realizing its full potential - is problematic not only because of its theoretical 
Manicheism. It is questionable also due to its historical inaccuracy. Early modern society, into which Hardt and Negri posit the origin of the modern multitude, was not based on the opposition between two monolithic forces, multitude and sovereignty. It was a deeply fragmented society in which royal sovereignty was not yet in place (Laclau, 2001). Royal sovereignty emerged only via a struggle with, on the one hand, local feudal powers, and, on the other, the universalistic powers of the church and the empire, with some of the newly arising social sectors, such as the bourgeoisie, helping to tip the scale of power in favor of royal sovereignty. By no means was this early modern multitude a unified and consistent political force that could establish an alternative social order. The alternative to the emergence of sovereign power was not a self-governing multitude, but the continuation of feudal fragmentation (Laclau, 2001, p. 6). Ironically, the multitude is a result of the process of the centralization of royal power, which, once it advanced beyond a point when local feudal and global universalistic powers no longer posed a serious threat to it, bestowed some of its sovereignty on the people.

The modern multitude of immaterial workers is not a subversive force inherently opposed to the state and capital. While it sometimes functions as an opposition to the state and capital, it does not operate as an actually existing multitude in power because the alleged non-antagonism between the various groups that compose it would soon crumble (Žižek, 2004, p. 198). A product of the struggle between various forces that reacted against the emerging centralized state, multitude has always been part of larger historical processes and group formations. It is only due to the interpretation of this multitude as an already formed and suppressed force awaiting liberation that Hardt and Negri can present immaterial labor as the multitude's spontaneously self-regulating activity that has no need to distance itself from what it does in order to critically evaluate what this activity represents and consider its external conditions of possibility. Hardt and Negri do not as much describe immaterial labor and analyze biopolitical mechanisms that sustain it, as they conceive of it as an abstract concept derived from a revolutionary essence and placed within an allegorical framework in which its role is to destroy the Empire. They pose both the telos and the means of reaching it, with the real purpose being 'to jump-start the revolutionary machine' (Lotringer, 2004, p. 16). Furthermore, it is not clear how the same global networks of communication and capital that produce the Empire become vehicles of the constituent power of the multitude (Dean, 2004, p. 267), and how the multitude as the 'sea' of networks will 'sweep away' imperial rule without some tactical coordination (Mertes, 2002 , p. 107). It should be underscored that the role of immaterial labor and the multitude cannot be determined by preconceived ideas about historical progress. Although capital always instigates resistance to its workings, the actions of the multitude and the future status of its labor practices are unpredictable. Immaterial labor is not the panacea for all the ills of modern work, in the same way as the multitude is not a manifestation of the end of the working class. Immaterial labor and the multitude are simply the current form of work and workers.

Hardt and Negri's, and to a lesser extent Virno's, understanding of biopower and immaterial labor hinges on an unstipulated acceptance of the status of work in modern society - a surprising acceptance, given the prominence of the theme of the refusal of work in Negri's early writings (Murphy, 2012, pp. 65-102; Weeks, 2005). Instead of 
critically examining the role of work in the biopolitical production of contemporary life, Hardt and Negri theorize immaterial labor's political potential. Hypostatizing immaterial labor as the current mode of the self-organization of human beings into a community, they are interested less in analyzing how this self-organization operates than in bringing to fruition its latent possibilities. Their primary objective is to look for alternatives to the status quo. Hence, those interpreters of Foucault who do not privilege the prognostic side of their inquiry over the diagnostic appear to them as leaving immaterial labor and the multitude powerless, with no subjectivity and no capability to act creatively and autonomously. For example, when Hardt and Negri discuss Giorgio Agamben's implementation of some of Foucault's ideas, they reproach him for this lack of positive solutions. They deem Agamben's notion of 'inoperative activity' (inoperosita) as a form of strategic rupture with biopower unacceptable because it is 'completely incapable of constructing an alternative' (Hardt and Negri, 2009, p. 58).

Notwithstanding the worthiness of Hardt and Negri's search for political alternatives, if the issue at hand is the relationship between biopower and immaterial labor, the principal goal is not to conceive of sites of autonomy and resistance that either elude power or creatively respond to it. Hardt and Negri's theory of immaterial labor's political potential rests on their understanding of biopower as power over life and biopolitics as a way of resisting biopower and producing alternatives to it. Indeed, biopower is a power that shapes life and biopolitics a power that emerges wherever biopower is applied. However, the problem is again Hardt and Negri's binarism. ${ }^{4}$ Since the uniqueness of biopower, as opposed to coercive power, is that it normalizes life by optimizing it and cultivating it, rather than disciplining it through punitive action, power and resistance when it comes to biopower are never in straightforward opposition (Foucault, 2007, pp. 1-2). Biopower and biopolitics are not two separate components of modern power, with the former preceding the latter. Even though biopolitics is a way of appropriating biopower - accepting it, resisting it or inventing alternative forms of its enactment - the former and the latter are inextricably intertwined. In the same way that biopower is not repression, biopolitics is not a spontaneous and power-free appropriation of the larger historical forces that compose biopower. While in principle Foucault's notion of biopower weakens the idea of autonomous action which creatively invents alternatives to power, this notion does not render biopolitical aspects of biopower, such as inoperativeness, futile, thus confirming that biopower permits only passivity. It is no coincidence that Agamben's concept of 'inoperativeness' relates explicitly to work. It is not devised as an activist notion, 'a blank refusal' (Hardt and Negri, 2009, p. 58) that fails to deliver what it promises because it sanctions only inactivity and resignation. This concept makes biopower and its limits apparent. Following Foucault's plea, Agamben draws attention to the central place of work in modern power structures. His concept reveals how work is becoming increasingly the supreme sphere of biopower's operations and the privileged means of integrating individuals into the economic and social system of contemporary society.

Organizing labor more through self-regulating practices and less through hierarchical structures is neither more nor less confining than any previous organization of labor. All modern labor is defined by the biopolitical production of life - not the principle of repression. The difference between disciplinary and biopolitical power is that in the latter, 
work decisively takes center stage. In the West, this crowning moment is a result of a process that began when the boundary between poiesis and praxis disintegrated - for the Greeks, Agamben reminds us, poiesis was not action but production in the sense of 'producing into presence', while for the Romans it was already a mode of agere, an act which brings something to actuality (Agamben, 1999, pp. 69-70) - with doing becoming willful activity with real effects, and work the underlying value of both poiesis and praxis. Foucault and Agamben agree: by the time of biopower all human doing has turned into praxis (concrete productive activity) anchored in work (the taking care of biological life), with people becoming producers who master their surroundings by working and who create themselves through work. The important point is not only how, but also that people in the modern era have been made into workers and work into an unquestioned value (Just, forthcoming).

\section{Conclusion}

Despite the increasing mechanization of work, working activity and its role in the current hegemony of immaterial labor has not become any less pervasive. If anything, the status of work has strengthened. Many mechanisms are now in place that have made workers personally invested in their work and the success of its products, and others that have reintroduced some of the older disciplinary methods, particularly into servicesector and knowledge-economy jobs (e.g. the new public management, financial auditing, risk management and performance-related pay). The result of these changes is the growing role of work both in personal life and in society at large. Slavoj Žižek quips that whenever one is personally invested in one's work, one is exposed to a superego pressure that is incomparably stronger than that of 'the good old "Protestant work ethic" '(1999, p. 368). We are proud to work hard, feel satisfied when we do so, and suffer from guilt when we do not. While immaterial labor allows for a degree of creativity and self-regulation, it also makes work spread into parts of society and the self that were not previously affected by it in any direct fashion. This spatial and temporal proliferation of work does not necessarily make immaterial labor a political force and a vehicle of the final social transformation, as Hardt and Negri believe. We should discuss immaterial labor's potential, but not at the expense of analyzing concrete labor practices and their effects. A return to Foucault is important as a means of tempering Hardt and Negri's optimism about the revolutionary nature of immaterial labor and the multitude. Immaterial labor is intertwined with the political not because it is an activity of the creative multitude. Both the multitude and immaterial labor are outcomes of a modern biopolitical operation of inscribing human life as animal laborans. We can neither predict where immaterial labor and the multitude will go from here, nor prescribe it. Foucault's lesson is to critically relate to the operation which valorizes work and turns people into workers, because it is this operation that makes us accept work as an unquestioned value instead of relativizing the status that biopower has conferred on it. Any radical political change, as Hardt and Negri imagine it, would have to be, above all, a reaction against this uncritical acceptance of work.

(Accepted: 28 September 2014) 


\section{Notes}

1 Foucault details how medieval society dealt with diseases. For instance, during leprosy epidemics the repressive method was used of removing the sick and confining them to areas outside of cities. During plagues, a different method was applied: a disciplinary strategy of partitioning cities, restricting people to certain zones and monitoring their movement (Foucault, 1995, pp. 195-9; 2003b, pp. 43-8; 2007, pp. 9-10).

2 Most other research on Foucault and the issue of work has been devoted to organizations, such as corporations and their control over their members, with the emphasis remaining on the surveilling and disciplining power rather than biopower (Burrell, 2006; Knights, 2002; McKinlay and Starkey, 1998).

3 Terrell Carver criticizes Hardt and Negri's enthusiasm and use of 'false universals', such as 'democracy', to substantiate their optimistic stance (Carver, 2006, pp. 354-5). Virno is more cautious than Hardt and Negri, calling attention to instances of discursive manipulations regarding labor. For example, his notion of the 'ideology of the possible' describes how the material requirement that workers adapt to continuous innovation has been ideologically transposed into an issue of 'opportunities' - a phantasmagoric ensemble of simultaneous options presented to individuals as their personal opportunities (Virno, 2007, p. 45).

4 Formulations suggesting Hardt and Negri's attempt to undo such binarism should be noted, as, for example, the following statement by Negri: 'To speak of biopolitics is to consider command and violence from below - that is, from a point of view opposed to that of biopower. And yet there is no possibility here of identifying a dialectic of the high and the low, or of an opposition between the high and the low... There is therefore no dialectic in the sense of an opposition between living within the structures of biopower, on the one hand, and freely and antagonistically travelling them as biopolitical subjects, on the other' (Negri, 2007, p. 50). This oscillation between a binary and non-binary theory of biopower and biopolitics in Hardt and Negri's work is analyzed by Toscano (2007).

\section{References}

Agamben, G. (1999) The Man without Content. Trans. G. Albert. Stanford, CA: Stanford University Press.

Arendt, H. (1958) The Human Condition. Chicago, IL: University of Chicago Press.

Arthur, M. B. and Rousseau, D. M. (eds) (2001) The Boundaryless Career: A New Employment Principle for a New Organizational Era. Oxford: Oxford University Press.

Beck, U. (2000) The Brave New World of Work. Cambridge: Polity Press.

Boltanski, L. and Chiapello, È. (2007) The New Spirit of Capitalism. Trans. G. Elliot. London: Verso.

Burrell, G. (2006) 'Foucauldian and Postmodern Thought and the Analysis of Work', in M. Korczynski, R. Hodson and P. Edwards (eds), Social Theory at Work. Oxford: Oxford University Press, pp. 155-81.

Carver, T. (2006) 'Less Than Full Marx', Political Theory, 34 (3), 351-6.

Casey, C. (1995) Work, Self and Society: After Industrialism. New York: Routledge.

Dean, J. (2004) 'The Networked Empire: Communicative Capitalism and the Hope for Politics', in P. A. Passavant and J. Dean (eds), Empire's New Clothes: Reading Hardt and Negri. New York: Routledge, pp. 267-90.

Fleming, P. (2009) Authenticity and the Cultural Politics of Work: New Forms of Informal Control. Oxford: Oxford University Press.

Foucault, M. (1978) The History of Sexuality, Vol. 1: An Introduction (The Will to Knowledge). Trans. R. Hurley. New York: Pantheon Books.

Foucault, M. (1995) Discipline and Punish: The Birth of the Prison. Trans. A. Sheridan. New York: Vintage Books.

Foucault, M. (2001a) 'Truth and Juridical Forms', in J. D. Faubion (ed.), Power: The Essential Works of Foucault, Vol. 3. Trans. R. Hurley. New York: New Press, pp. 1-89.

Foucault, M. (2001b) 'The Politics of Health in the Eighteenth Century', in J. D. Faubion (ed.), Power: The Essential Works of Foucault, Vol. 3. Trans. R. Hurley. New York: New Press, pp. 90-105.

Foucault, M. (2003a) Society Must Be Defended: Lectures at the College de France, 1975-1976. Trans. D. Macey. New York: Picador.

Foucault, M. (2003b) Abnormal: Lectures at the College de France, 1974-1975. Trans. G. Burchell. London: Verso.

Foucault, M. (2007) Security, Territory, Population: Lectures at the Collège de France, 1977-1978. Trans. G. Burchell. Basingstoke: Palgrave Macmillan.

Foucault, M. (2008) The Birth of Biopolitics: Lectures at the College de France, 1978-1979. Trans. G. Burchell. Basingstoke: Palgrave Macmillan.

Gorz, A. (1999) Reclaiming Work: Beyond the Wage-Based Society. Trans. C. Turner. Cambridge: Polity Press.

Gottschall, K. and Wolf, H. (2007) 'Introduction: Work Unbound', Critical Sociology, 33 (1-2), 11-8.

Hall, P. A. and Soskice, D. (2001) 'An Introduction to Varieties of Capitalism', in P. A. Hall and D. Soskice (eds), Varieties of Capitalism: The Institutional Foundations of Comparative Advantage. Oxford: Oxford University Press, pp. 1-68.

Hardt, M. and Negri, A. (1994) Labor of Dionysus: A Critique of the State-Form. Minneapolis, MN: University of Minnesota Press.

Hardt, M. and Negri, A. (2000) Empire. Cambridge, MA: Harvard University Press.

Hardt, M. and Negri, A. (2004) Multitude: War and Democracy in the Age of Empire. New York: Penguin Press.

Hardt, M. and Negri, A. (2009) Commonwealth. Cambridge, MA: Harvard University Press.

Holloway, J. (2010) Crack Capitalism. London: Pluto Press.

Just, D. (forthcoming) 'The Invention of Work in Modernity: Hegel, Marx, and Weber', Journal of Historical Sociology. 
Kalleberg, A. L. (2009) 'Precarious Work, Insecure Workers: Employment Relations in Transition', American Sociological Review, 74 (1), 1-22.

Knights, D. (2002) 'Writing Organizational Analysis into Foucault', Organization, 9 (4), 575-94.

Laclau, E. (2001) 'Can Immanence Explain Social Struggles?', Diacritics, 31 (4), 3-10.

Lotringer, S. (2004) 'Foreword: We, the Multitude', in P. Virno, A Grammar of the Multitude: For an Analysis of Contemporary Forms of Life. Trans. I. Bertoletti, J. Cascaito and A. Casson. New York: Semiotext[e], pp. 7-19.

Luke, T. W. (2006) 'Material Concerns about Immaterial Labor and Democracy in Multitude', Political Theory, 34 (3), 365-71.

Marx, K. (1991) Capital: A Critique of Political Economy. Vol. 3. Trans. D. Fernbach. London: Penguin.

McKinlay, A. and Starkey, K. P. (eds) (1998) Foucault, Management and Organization Theory: From Panopticon to Technologies of Self. London: Sage.

Mertes, T. (2002) 'Grass-Roots Globalism: Reply to Michael Hardt', New Left Review, 17, 101-10.

Muirhead, R. (2004) Just Work. Cambridge, MA: Harvard University Press.

Murphy, T. S. (2012) Antonio Negri: Modernity and the Multitude. Cambridge: Polity Press.

Negri, A. (2007) 'Art and Culture in the Age of Empire and the Time of the Multitudes'. Trans. M. Henninger. SubStance: A Review of Theory and Literary Criticism, 36 (1), 48-55.

Rifkin, J. (1996) The End of Work. New York: G. I. Putnam's Sons.

Ross, A. (2004) No-Collar: The Humane Workplace and Its Hidden Costs. Philadelphia, PA: Temple University Press.

Schumpeter, J. A. (2003) Capitalism, Socialism and Democracy. New York: Routledge.

Toscano, A. (2007) 'Always Already Only Now: Negri and the Biopolitical', in T. S. Murphy and A. K. Mustapha (eds), The Philosophy of Antonio Negri, Vol. 2: Revolution in Theory. London: Pluto Press, pp. 109-28.

Virno, P. (2004) A Grammar of the Multitude: For an Analysis of Contemporary Forms of Life. Trans. I. Bertoletti, J. Cascaito and A. Casson. New York: Semiotext[e].

Virno, P. (2007) ' "Wage Labor” and "Post-Fordist Semblance"'. Trans. M. Henninger. SubStance: A Review of Theory and Literary Criticism, 36 (1), 42-6.

Weeks, K. (2005) 'The Refusal of Work as Demand and Perspective', in T. S. Murphy and A. K. Mustapha (eds), The Philosophy of Antonio Negri, Vol. 1: Resistance in Practice. London: Pluto Press, pp. 109-35.

Weeks, K. (2011) The Problem with Work: Feminism, Marxism, Antiwork Politics and Postwork Imaginaries. Durham, NC: Duke University Press.

Žižek, S. (1999) The Ticklish Subject: The Absent Centre of Political Ontology. London: Verso.

Žižek, S. (2004) Bodies without Organs. New York: Routledge.

\section{About the Author}

Daniel Just is Assistant Professor in the Department of Political Science at Bilkent University. He is the author of Literature, Ethics and Decolonization in Postwar France: The Politics of Disengagement (Cambridge University Press), and a number of journal articles that have appeared, among others, in Modern Language Review, New Literary History, MLN, Forum for Modern Language Studies, Philosophy and Literature, Journal of European Studies and European Journal of Cultural Studies. Daniel Just, Department of Political Science, Bilkent University, Ankara 06800, Turkey; email: just@ bilkent.edu.tr 